\title{
Effects of Kaolinite (Macsumsuk) and Herb Mixtures on the Quality and Physicochemical Properties of Pork
}

\author{
Byung Ki Kim¹, Eun Gyeong Hwang², Dae Jin Jung ${ }^{1}$, Jae Jung Ha¹, Dong Yep Oh${ }^{1}$, and Chang Bon Choi* \\ School of Biotechnology, Yeungnam University, Gyeongsan 712-706, Korea \\ ${ }^{1}$ Gyeongsangbuk-do Livestock Research Institute, Yeoungju 750-871, Korea \\ ${ }^{2}$ Department of Hotel Culinary Art, Mungyeong College, Mungyeong 745-706, Korea
}

\begin{abstract}
The current study was conducted to identify technology for the production of high quality pork, based on the meat consumption habits of consumers. Macsumsuk, a type of kaolinite (a clay mineral), and/or a mixture of herbs (Mori Folium, Sophorae Radix, Glycyrrhizae Radix, Citri Leiocarpae Exocarpium, and Pogostemi Herba) were added to the diets of fattening pigs. Sixty barrow pigs ( 4 kinds of treatment $\times 5$ pigs/treatment $\times 3$ replicates) were randomly assigned to either the Control (no additives), T1 (3\% Macsumsuk), T2 (3\% Herb mixtures), or T3 (3\% Macsumsuk $+3 \%$ Herb mixtures) groups, and were fed the diets for $60 \mathrm{~d}$. Dressed weights were in the order of T1 $(93.40 \pm 4.68 \mathrm{~kg})>\mathrm{T} 2(91.40 \pm 6.52 \mathrm{~kg})>\mathrm{Control}(88.80 \pm 1.57$ $\mathrm{kg})>\mathrm{T} 3(86.80 \pm 2.01 \mathrm{~kg})$. Back-fat thickness of the Control animals $(23.2 \pm 1.03 \mathrm{~mm})$ was significantly greater than that of the various treatment groups $(p<0.01)$. Numeric values representing the carcass yield and quality grade were higher for all the treated groups than the Control group, thought the difference was not statistically significant. Crude fat content was significantly higher in the Control group $(2.23 \pm 0.34 \%)$ than in the treated groups $(p<0.05)$. The addition of both Macsumsuk and herb mixtures into the diets of the pigs significantly reduced cooking loss of the pork compared to the Control $(p<0.05)$. No statistically significant changes were observed in the shear force (average $5.87 \pm 0.54 \mathrm{~kg} / \mathrm{cm}^{2}$ ), water holding capacity (average $54.59 \pm 3.16 \%$ ), or CIE values of the pork, whereas cholesterol levels significantly decreased $(p<0.01)$ in those fed Macsumsuk and/or the herb mixtures. No significant changes in fatty acid composition, total saturated fatty acid (SFA), total unsaturated fatty acid (UFA), or UFA/SFA ratios were observed by any of the treatments. In conclusion, the results obtained from this study suggest that the addition of Macsumsuk and/or herb mixtures into the diets of growing and fattening pigs improves the pork quality by reducing cooking loss, decreasing cholesterol content, and enhancing sensory characteristics.
\end{abstract}

Key words: Macsumsuk, herb mixtures, pigs, yield grade, quality grade

\section{Introduction}

Improved pork production technologies that increase meat quality are necessary to increase competitiveness in the era of free trade agreement (FTA). The use of feed additives is a popular method practiced by farming operations to produce high quality pork (Kim et al., 2010; Kim et al., 2011). Macsumsuk and herbs are commonly used to improve meat quality in the South Korean swine industry. In general, clay minerals are produced as a secondary product produced by a reaction of silicon, aluminum, and water during the weathering of hard stones. Clay minerals are classified as kaolinite, zeolite, illite and

*Corresponding author: Chang Bon Choi, School of Biotechnology, Yeungnam University, Gyeongsan 712-706, Korea. Tel: +82-53-810-3023, Fax: +82-53-810-4769, E-mail: cbchoi@yu. ac.kr smectite. Kaolinite is soft and has soil-like nature. White mineral (layered silicate clay with octahedron) is produced by chemical weathering of aluminum silicates such as feldspars. Pink, orange, or red color is caused by ferrite which gives rusty color. It protects mucosal layers of intestine and effective in preventing diarrhea. Zeolite is Silicate clay minerals composed of aluminum, sodium, and calcium. It improves feed efficiency and prevents runny stools by excellent cation exchanging effects. Illite is micro particle $(2-4 \mu \mathrm{m})$ silicate clay minerals similar to mica. It activates cells by emitting a negatively charged ions and far-infrared radiation and enhances immunity and fungiatatic action. Smectite is modified glass constituent clay minerals produced by volcano activity. It is excellent in removing body wastes because of its high adsorbalility. Negatively charged surfaces of bentonite clay attract and excrete positively charged toxins, heavy minerals, and active oxygen. 
These minerals are unable to undergo spontaneous chemical reactions because they are natural inorganic nonminerals, and are insoluble in acids or alkalis (Kim et al., 2011). Addition of clay minerals to the diets of livestock can stimulate body growth, improve feed efficiency, control moisture contents while eliminating unpleasant odors in feces (Son et al., 1998), and can increase nutrient digestibility by delaying the passage of food particles through the gut (Harms and Darmron, 1973). Supplementation with zeolite up to $5 \%$ of the diets of livestock eliminates fecal odor, controls moisture in meat, and reduces nitrogen excretion (Kovar et al., 1990). Consumption of this mineral also alters the fatty acid composition of porcine and chicken muscles, helps prevent diseases, and reduces the incidence of diarrhea (England, 1975).

When bioceramics emitting infrared rays were added to the diets of growing pigs, the number of colitis germs was decreased whereas the Lactobacillus population was increased, resulting in improved immune reactions (Kwon, 2001). Additionally, the addition of dietary silicates in fattening pigs improved pork palatability by reducing odors while enhancing juiciness and tenderness of the meat, and extended pork shelf-life by delaying acidification (Kong et al., 2004). Moreover, total cholesterol levels, LDL concentrations, and arteriosclerosis indices were reduced by the addition of bioceramics with $0.1 \sim 0.2 \%$ of herbal medicine by-products to the diet of fattening pigs (Cho et al., 2004). Supplementation with mugwort pellets (Kim et al., 2004) and residues of herbal medicines (Park et al., 1998) in the diets of fattening castrated pigs reduced fat contents of the carcass, and improved tenderness, flavor, and color of the meat. Powdered persimmon peel in pig diets increased total cholesterol and HDL levels, and increased consumer purchasing desire by improving meat tenderness, flavor, and juiciness (Kim et al., 2011).

The current study was conducted to measure the effects of dietary Macksumsuk (GM, 2010) and herbs (Glycyrrhizac Radix, detoxification and anti-allergic effects; Pogostemi Herba, anti-bacterial effects; Sophorae Radix, stomach strengthening, fever alleviation, parasiticidic effects, and suppression of neuralgia; Fraxini Cortex, diuretic and capillary strengthening; and Mori Folium, antibacterial effects) on the physicochemical characteristics and quality of pork from fattening pigs. Macksumsuk is a clay mineral belonging to the kaolinite family with a $\mathrm{pH}$ of 10 emitting infrared rays of $108-133 \mathrm{~Hz}$ and containing $\mathrm{SiO}_{2}$ (73.0\%), $\mathrm{Al}_{2} \mathrm{O}_{3}(13.8 \%), \mathrm{Fe}_{2} \mathrm{O}_{3}(3.04 \%)$, and $\mathrm{CaO}(2.34 \%)$. The herbs added to the pig diet are known to have antibacterial properties and stimulate the growth of fattening pigs (Park, 2002).

\section{Materials and Methods}

\section{Animals and diets}

Sixty (four treatments $\times$ five heads/treatment $\times$ three replica) three-way crossbred Landrace and Duroc castrated male piglets in the local farm were randomly divided into one of four treatment groups: Control (no additives), T1 (0.3\% Macsumsuk), T2 (0.3\% herb mixture), and $\mathrm{T} 3$ $(0.3 \%$ Macsumsuk $+0.3 \%$ herb mixture). The animals were housed at a local farm and fed the experimental diets for $60 \mathrm{~d}$. Commercial concentrates (Nonghyup feed, Co.) were used as an experimental basal diet. Chemical composition of the diets was analyzed using the AOAC methods (2004). Dietary ingredients and chemical composition of the basal concentrates are shown in Table 1 .

Table 1. Ingredients and chemical composition of the experimental diets

\begin{tabular}{|c|c|c|}
\hline Ingredient (\%) & $\begin{array}{c}\text { Growing } \\
(50-80 \mathrm{~kg}) \\
\end{array}$ & $\begin{array}{c}\text { Fattening } \\
(80-120 \mathrm{~kg})\end{array}$ \\
\hline Corn & 45.52 & 42.12 \\
\hline Wheat & 13.00 & 13.00 \\
\hline Lupin & 2.50 & 2.50 \\
\hline Rice bran & 4.00 & 8.80 \\
\hline Soybean meal & 19.85 & 17.40 \\
\hline Rapeseed meal & 2.44 & 4.58 \\
\hline Sesame meal & 3.00 & 2.00 \\
\hline Limestone & 0.61 & 0.61 \\
\hline Calcium phosphate & 0.77 & 0.75 \\
\hline Salt & 0.31 & 0.31 \\
\hline Tallow & 4.52 & 4.52 \\
\hline Molasses & 3.00 & 3.00 \\
\hline L-lysine, 98\% & 0.14 & 0.14 \\
\hline Vitamin primix ${ }^{1)}$ & 0.15 & 0.11 \\
\hline Mineral primix ${ }^{2)}$ & 0.15 & 0.12 \\
\hline Choline chloride, $50 \%$ & 0.04 & 0.04 \\
\hline Total & 100 & 100 \\
\hline \multicolumn{3}{|c|}{ Chemical composition (\%) } \\
\hline Moisture & 9.99 & 10.42 \\
\hline Crude protein & 18.12 & 15.54 \\
\hline Crude fat & 4.90 & 4.30 \\
\hline Crude fiber & 6.13 & 6.83 \\
\hline Crude ash & 8.25 & 8.21 \\
\hline $\mathrm{Ca}$ & 0.58 & 0.46 \\
\hline $\mathrm{P}$ & 1.30 & 1.30 \\
\hline ME (kcal/kg) & 3,350 & 3,300 \\
\hline
\end{tabular}

${ }^{1)}$ Vitamin premix: $12,000,000 \mathrm{IU}$ vitamin A, 2,400,000,000 IU vitamin $D_{3}, 1,500 \mathrm{mg}$ vitamin $E, 2,500 \mathrm{mg}$ vitamin $B_{1}, 4,000 \mathrm{mg}$ vitamin $B_{2}, 2,000 \mathrm{mg}$ vitamin $B_{6}, 20 \mathrm{mg}$ vitamin $B_{12}, 12,000 \mathrm{mg}$ pantothenic acid, 40,000 mg niacin, $30 \mathrm{mg}$ biotin, 1,000 mg folic acid, and 6,000 $\mathrm{mg}$ antioxidant.

${ }^{2}$ Mineral premix: 8,000 mg Cu, 50,000 mg Fe, 70,000 mg Mn, $200 \mathrm{mg} \mathrm{Se}$, and 50,000 $\mathrm{mg} \mathrm{Zn.}$ 
Table 2. Chemical composition of Macsumsuk and the herb mixture used in this study

\begin{tabular}{ccccccc}
\hline \hline $\begin{array}{c}\text { Chemical } \\
\text { composition (\%) }\end{array}$ & Macsumsuk & Mori Folium & Sophorae Radix & $\begin{array}{c}\text { Glycyrrhizae } \\
\text { Radix }\end{array}$ & $\begin{array}{c}\text { Citri Leiocarpae } \\
\text { Exocarpium }\end{array}$ & $\begin{array}{c}\text { Pogostemi Herba } \\
\text { Moisture }\end{array}$ \\
\hline Crude protein & 0.75 & 8.50 & 7.00 & 6.10 & 11.10 & 8.57 \\
Crude fat & 0.24 & 14.81 & 11.35 & 9.36 & 5.09 & 6.78 \\
Crude fiber & - & 5.67 & 2.19 & 3.37 & 3.36 & 2.76 \\
Crude ash & - & 53.49 & 20.46 & 13.96 & 9.47 & 31.40 \\
\hline
\end{tabular}

Estimation data

Chemical compositions of the Macsumsuk and herb mixtures are presented in Table 2. Macsumsuk used for the T1 diet was powdered with a mesh (325 size) and mixed with the basal diet after making for $4 \mathrm{~h}$ at $850-950^{\circ} \mathrm{C}$. Equal amounts of commercial natural herbs (Glycyrrhizac Radix, Sophorae Radix, Pogostemi Herba, Fraxini Cortex, and Mori Folium) used for the T2 diet were powdered and mixed together. Macsumsuk and the herb mixture used for the T3 diet were combined at a 1:1 (w/ w) ratio.

\section{Evaluation of physicochemical characteristics of the pork}

After terminating the experiment, the pigs were transported to a local livestock processing complex (LPC) and slaughtered. The carcass grade was determined based on the Korean Pig Carcass Grading Standard (Ministry of Agriculture, Food and Rural Affairs, notice 2013-109), and meat samples from the loin were obtained for chemical analysis. Moisture, crude protein, crude fat, and crude ash contents were analyzed using the AOAC method (2004). Cooking loss of the pork was measured by calculating the percentages (\%) of lost weight after cooking 50 $\mathrm{g}$ of pork at $70^{\circ} \mathrm{C}$ in a water bath for $30 \mathrm{~min}$. Minced samples $(10 \mathrm{~g})$ of pork were combined with $90 \mathrm{~mL}$ distilled water and homogenized (NS-50, Scientific Co., Japan) at 10,000 rpm for $1 \mathrm{~min}$. pH of the meat was then measured using a $\mathrm{pH}$ meter (Orion Research Inc., USA). Shear force of the pork $(2 \mathrm{~mm} \times 5 \mathrm{~mm}$ samples $)$ was measured parallel to the muscle fibers using a rheometer (CR-300, Sun Scientific Co., Japan). Operating conditions of the rheometer were $120 \mathrm{~mm} / \mathrm{min}$ table speed, 80 $\mathrm{mm} / \mathrm{sec}$ chart speed, $5 \mathrm{~mm}$ sample height, and $1 \mathrm{~kg}$ load cell. Shear force is expressed as $\mathrm{kg} / \mathrm{cm}^{2}$. Water holding capacity (WHC) of the pork was evaluated by cooking (20 min) minced samples (10 g) in a centrifuge tube with a fritted glass disk (Difco, USA) for 30 minutes at $4^{\circ} \mathrm{C}$ and centrifuging at $1,000 \mathrm{~g}$ for $10 \mathrm{~min}$ after cooling. The volume of meat juices in the lower part of the tube was measured and the WHC was calculated using the equa- tion:

WHC $(\%)=$ extracted meat juice $(\mathrm{mL}) \times 0.951 /$ total moisture in the sample $(\mathrm{g}) \times 100$

Meat color was assessed using a colorimeter (CR-300, Minolta Camera Co., Japan) after exposure to air for 30 minutes. Results are expressing as Hunter values $\left(\mathrm{L}^{*}=\right.$ lightness, $\mathrm{a}^{*}=$ redness, and $\mathrm{b}^{*}=$ yellowness $)$. The standard color plate used was a white calibration plate for which $L^{*}=96.18, a^{*}=0.10$, and $b^{*}=1.90$. An average of three replicate measurements was taken. Sensory evaluation of the pork was performed by trained panelists. Results are expressed using a 6 -point scale measuring juiciness $(1=$ very dry to $6=$ very juicy), tenderness $(1=$ very hard to $6=$ very soft), flavor $(1=$ very unfavorable to $6=$ very favorable), and overall acceptability ( $1=$ greatly dislike, $6=$ like very much).

\section{Measurement of cholesterol contents}

Analysis of the pork cholesterol contents was performed as previously described by Nam et al. (2001). Two g of pork sample, $10 \mathrm{~mL}$ of saponification reagent and 0.5 $\mathrm{mL}$ of an internal standard (5-cholestane, Difco, USA) were mixed in a 50-mL tube, and homogenized for $14 \mathrm{sec}$ at 9,500 $\mathrm{g}$. The closed tube was heated for $1 \mathrm{~h}$ at $60^{\circ} \mathrm{C}$ and $1 \mathrm{~mL}$ of supernatant was dried after cooling at room temperature. After drying, the fat was completely dissolved by adding $200 \mathrm{~L}$ pyridine and $100 \mathrm{~L}$ sylon BFT (bistrifluoro-actamide : trimethyl-chlorosilane $=99: 1$ ). Cholesterol concentrations were analyzed using gas chromatography (GC; HP-6890, Agilent Technologies, USA). Operating conditions for GC were oven temperature of $180^{\circ} \mathrm{C}$, injection temperature of $280^{\circ} \mathrm{C}, 19.1: 1$ split ratio for the column : capillary column, $30 \mathrm{~m} \times 0.32 \mathrm{~mm}$ I.D., film thickness of $0.25 \mathrm{~m}$ (HP-5MS; J \& W Scientific, USA), maximum oven temperature of $325^{\circ} \mathrm{C}$, flame ionization detector temperature of $350^{\circ} \mathrm{C}$, and $33.0 \mathrm{~mL} / \mathrm{min}$ $\mathrm{H}_{2}$ flow. 


\section{Fatty acid analysis}

Lipids were extracted from the pork samples as previously described by Folch et al. (1957). One hundred grams $(100 \mathrm{~g})$ of each sample was homogenized with a tissue grinder (1102-1; Tokyo Rikakikai Co., Japan). Ten-fold greater volume of the chloroform : methanol $(2: 1, \mathrm{v}: \mathrm{v})$ mixture was added and the solution was incubated overnight at room temperature. The supernatant was then removed and the infranatant was filtered after dehydrating by adding anhydrous $\mathrm{Na}_{2} \mathrm{SO}_{4}$. The solvent was evaporated with a rotary evaporator (EYELA A-3S; Tokyo Rikakikai Co., Japan) below $50^{\circ} \mathrm{C}$. The total recovered lipid was transferred into a brown container with nitrogen gas and stored in a freezer until analysis.

To analyze the fatty acid composition, $0.5 \mathrm{~g}$ of extracted lipid was methylated as previously described by Park and Goins (1994). Methanol : benzene (4:1, v:v; $2 \mathrm{~mL}$ ) and acetyl chloride $(200 \mathrm{~L})$ were added to the lipid and the solution was heated for $1 \mathrm{~h}$ at $100^{\circ} \mathrm{C}$ on a heating block. After cooling, $1 \mathrm{~mL}$ hexane and $5 \mathrm{~mL} \mathrm{6 \%}$ potassium carbonate were added, and the solution was centrifuged for $15 \mathrm{~min}$ at $3,000 \mathrm{~g}$ at room temperature. Next, $0.5 \mathrm{~L}$ of supernatant was injected into a gas chromatography apparatus (GA-17A; Shimadzu Co., Japan). The column temperature was initially $180^{\circ} \mathrm{C}$, gradually $\left(1.5^{\circ} \mathrm{C} / \mathrm{min}\right)$ increased to $230^{\circ} \mathrm{C}$, and maintained for $2 \mathrm{~min}$. Temperature of the injector and detector (FID) was $240^{\circ} \mathrm{C}$ and $260^{\circ} \mathrm{C}$, respectively. Retention time for each fatty acid peak was compared to that of the standard and the composition was calculated as percentages (\%).

\section{Statistical analysis}

The data were subjected to statistical analysis after data coding and data cleaning. The statistical analysis was conducted using the Statistical Package for Social Sci- ence software (SPSS v. 17.0, 2010). Differences of mean values between the treatment groups were compared with a one-way analysis of variance (ANOVA) and significance was tested by Duncan's multiple tests (1955).

\section{Results and Discussion}

\section{Weight gain and carcass grade}

Body weight (BW) and carcass data of the experimental pigs are shown in Table 3. Initial BW was similar among the experimental groups with an overall average of $57.88 \pm 7.29 \mathrm{~kg}$. After $60 \mathrm{~d}$ of the experiment, T2 $(126.90 \pm 3.50 \mathrm{~kg})$ and T3 $(126.40 \pm 4.60 \mathrm{~kg})$ groups fed the herb mixture or Macsumsuk + herb mixture, respectively, had a higher BW $(p<0.05)$ than the Control $(120.50 \pm 4.40$ $\mathrm{kg})$ and $\mathrm{T} 1(120.70 \pm 4.50 \mathrm{~kg})$ groups. This might have been caused by increased feed intake and digestibility due to enhanced palatability attributed to the herbs included in the $\mathrm{T} 2$ and $\mathrm{T} 3$ experimental diets. The current $\mathrm{BW}$ results coincide with those of previous reports by Kondo and Wagai (1968) as well as Hong (2006) showing a 25-29\% and $14 \%$ increase in weight gain with zeolite or Lonicerac Caulis et Folium administration, respectively, and a 6-35\% improvement in feed efficiency.

Addition of Lonicerac Caulis et Folium into diets of pigs reduced feed intake while increased weight gain which improved feed efficiency (Hong, 2006) and addition of $0.3 \%$ of germanium biotite in the diets of fattening pigs increased weight gain $14 \%$ and improved feed efficiency (Kwon, 2001). These results suggest that feeding herb mixtures and kaolinite (Macsumsuk) mixed with herb mixtures increases weight gain by improving feed intake and nutrients digestibility.

Dressing weight tended to be slightly higher for the $\mathrm{T} 1$ $(93.40 \pm 4.68 \mathrm{~kg})$ group compared to the other groups. The

Table 3. Effects of Macsumsuk and the herb mixture on pig carcass traits

\begin{tabular}{cccccccc}
\hline \hline Items & Control $^{\mathrm{I}}$ & $\mathrm{T}^{2)}$ & $\mathrm{T}^{\mathrm{j}}$ & T3 $^{4)}$ & Average & F-value & P-value \\
\hline Initial weight (kg) & $58.20 \pm 8.20$ & $57.60 \pm 7.40$ & $58.10 \pm 7.50$ & $57.60 \pm 9.10$ & $57.88 \pm 7.29$ & - & - \\
Final weight (kg) & $120.50^{\mathrm{a}} \pm 4.40$ & $120.70^{\mathrm{a}} \pm 4.50$ & $126.90^{\mathrm{b}} \pm 3.50$ & $126.40^{\mathrm{b}} \pm 4.60$ & $124.63 \pm 3.80$ & 8.544 & 0.003 \\
Feed intake / day (kg) & $3.03 \pm 0.17$ & $2.91 \pm 0.07$ & $2.98 \pm 0.11$ & $2.98 \pm 0.11$ & $2.98 \pm 0.12$ & 0.675 & 0.584 \\
Feed conversion rate & $2.92^{\mathrm{b}} \pm 0.11$ & $2.62^{\mathrm{a}} \pm 0.11$ & $2.65^{\mathrm{a}} \pm 0.07$ & $2.65^{\mathrm{a}} \pm 0.07$ & $2.71 \pm 0.15$ & 9.839 & 0.041 \\
Dressing weight (kg) & $88.80 \pm 1.57$ & $93.40 \pm 4.68$ & $91.40 \pm 6.52$ & $86.80 \pm 2.01$ & $91.25 \pm 4.12$ & 0.787 & 0.524 \\
Dressing percent (\%) & $73.69 \pm 1.27$ & $74.89 \pm 4.89$ & $72.03 \pm 5.36$ & $74.74 \pm 1.44$ & $73.16 \pm 3.58$ & 0.553 & 0.656 \\
Back-fat thickness (cm) $^{2}$ & $23.20^{\mathrm{b}} \pm 1.03$ & $19.60^{\mathrm{a}} \pm 1.36$ & $18.41^{\mathrm{a}} \pm 4.20$ & $19.20^{\mathrm{a}} \pm 0.46$ & $19.91^{\mathrm{a}} \pm 2.87$ & 3.961 & 0.036 \\
Yield grade $^{5)}$ & $3.60 \pm 0.49$ & $3.80 \pm 0.80$ & $3.76 \pm 0.21$ & $3.80 \pm 0.21$ & $3.73 \pm 0.45$ & 0.131 & 0.940 \\
Quality grade $^{6)}$ & $2.70 \pm 0.29$ & $2.90 \pm 0.18$ & $2.94 \pm 0.51$ & $2.94 \pm 0.10$ & $2.87 \pm 0.30$ & 0.538 & 0.665 \\
\hline
\end{tabular}

Data are presented as the mean $\pm \mathrm{SD}$

${ }^{a, b}$ Means with different superscripts in the same row are significantly different $(p<0.05)$.

${ }^{1)}$ Control: basal concentrate, ${ }^{2)} \mathrm{T} 1: 0.3 \%$ Macsumsuk powder, ${ }^{3)} \mathrm{T} 2: 0.3 \%$ herb mixture, ${ }^{4)} \mathrm{T} 3: 0.3 \%$ Macsumsuk powder $+0.3 \%$ herb mixture, ${ }^{5}$ Converted into numeric values: $\mathrm{A}=4, \mathrm{~B}=3, \mathrm{C}=2$, and $\mathrm{D}=1,{ }^{6}$ Converted into numeric values: $1^{+}=4,1=3,2=2,3=1$ 
overall average dressing percentage was $73.16 \pm 3.58 \%$. Back-fat thickness of the Control group (23.20 $\pm 1.03 \mathrm{~mm})$ was the greatest $(p<0.05)$ compared to that of the other treatment groups. This result was similar to those of previous reports demonstrating that feeding $3.0 \%$ biotite germanium to fattening pigs significantly decreased back-fat thickness (Kwon, 2001) while a mixture of Astragali Radix, Ginseng Radix, and onion improved carcass grade (Hong et al., 2001; Ryu and Song, 1999). These findings imply that the addition of Macsumsuk and herb powders is effective for decreasing back-fat thickness of pigs. Dietary supplementation with Macsumsuk and herb mixtures in fattening pigs may increase the yield and quality of pork although no statistical differences among the experimental groups were observed. As a result, live body weight and carcass weight were increased by synergistic effects of kaolinite (Macsumsuk) and herb mixtures which improved palatability of feed and hence increased feed intake and enhanced immunity of the animals, respectively. Furthermore, carcass grade was improved by reduced backfat thickness of pork because of interactions of herb mixtures and kaolinite (Macsumsuk) which resulted in decrease in cholesterol contents and saturated fatty acids in the carcass.

\section{Physicochemical characteristics of the pork}

Chemical composition as well as moisture, crude protein, crude fat, and crude ash contents of the pork are shown in Table 4. Overall average moisture and crude protein contents were $73.88 \pm 0.69 \%$ and $22.85 \pm 0.69 \%$, respectively. No significant differences were observed among the groups. Crude fat content of the T3 group $(1.78 \pm 0.12 \%)$ was significantly lower $(p<0.05)$ than that of the Control group $(2.23 \pm 0.34 \%)$. Pond et al. (1988) reported that zeolite is beneficial, and improves the muscle and fat characteristics of pork. Hong (2006) determined that consumption of Lonicerac Caulis et Folium by growing pigs reduces crude fat contents. Based on the results of the current study and previous reports, Macsumsuk and herb mixtures appear to reduce the fat contents of pork.

Physicochemical properties of the pork are shown in Table 5. The addition of Macsumsuk and the herb mixture to the diets of fattening pig significantly decreased $(p$

Table 4. Effects of Macsumsuk and the herb mixture on pork chemical composition

\begin{tabular}{cccccccc}
\hline \hline Items (\%) & Control $^{1)}$ & T1 $^{2)}$ & T2 $^{3)}$ & T3 & Average & F-value & P-value \\
\hline Moisture & $73.81 \pm 0.82$ & $74.08 \pm 0.17$ & $74.14 \pm 0.24$ & $73.49 \pm 1.01$ & $73.88 \pm 0.65$ & 0.789 & 0.523 \\
Crude protein & $23.15 \pm 0.77$ & $22.60 \pm 0.40$ & $22.80 \pm 0.61$ & $22.87 \pm 1.02$ & $22.85 \pm 0.69$ & 0.383 & 0.767 \\
Crude fat & $2.23^{\mathrm{b}} \pm 0.34$ & $1.84^{\mathrm{a}} \pm 0.08$ & $1.97^{\mathrm{ab}} \pm 1.00$ & $1.78^{\mathrm{a}} \pm 0.12$ & $1.96 \pm 0.25$ & 4.439 & 0.026 \\
Crude ash & $0.82 \pm 0.04$ & $0.78 \pm 0.13$ & $0.80 \pm 0.23$ & $0.88 \pm 0.05$ & $0.82 \pm 0.05$ & 4.716 & 0.021 \\
\hline
\end{tabular}

Data are presented as the mean \pm SD.

${ }^{\mathrm{a}, \mathrm{b}}$ Means with different superscripts in the same row are significantly different $(p<0.05)$.

${ }^{1)}$ Control: basal concentrate, ${ }^{2} \mathrm{~T} 1: 0.3 \%$ Macsumsuk powder, ${ }^{3)} \mathrm{T} 2: 0.3 \%$ herb mixture, and ${ }^{4} \mathrm{~T} 3: 0.3 \%$ Macsumsuk powder $+0.3 \%$ herb mixture

Table 5. Effects of supplementation with Macsumsuk and herb powders on the physicochemical properties of pork from growing-finishing pigs

\begin{tabular}{|c|c|c|c|c|c|c|c|c|}
\hline \multicolumn{2}{|c|}{ Items } & Control $^{\mathrm{I})}$ & $\overline{T 1^{21}}$ & $\mathrm{~T}^{3)}$ & $\mathrm{T}^{4)}$ & Average & F-value & P-value \\
\hline \multicolumn{2}{|c|}{ Cooking loss (\%) } & $35.63^{\mathrm{b}} \pm 0.43$ & $33.07^{\mathrm{a}} \pm 0.98$ & $34.17^{\mathrm{a}} \pm 0.60$ & $34.17^{\mathrm{a}} \pm 0.63$ & $34.26 \pm 1.12$ & 9.277 & 0.012 \\
\hline \multicolumn{2}{|c|}{ Shear force value $\left(\mathrm{kg} / \mathrm{cm}^{2}\right)$} & $6.19 \pm 0.86$ & $5.53 \pm 0.53$ & $5.88 \pm 0.32$ & $5.88 \pm 0.19$ & $5.87 \pm 0.54$ & 1.013 & 0.421 \\
\hline \multicolumn{2}{|c|}{ Water holding capacity (\%) } & $53.98 \pm 0.82$ & $54.65 \pm 4.00$ & $54.88 \pm 3.50$ & $54.88 \pm 4.52$ & $54.59 \pm 3.16$ & 0.059 & 0.980 \\
\hline \multicolumn{2}{|c|}{ Cholesterol content $(\mathrm{mg} / 100 \mathrm{~g})$} & $42.03^{\mathrm{C}} \pm 0.78$ & $36.15^{\mathrm{B}} \pm 1.58$ & $34.10^{\mathrm{A}} \pm 0.96$ & $34.10^{\mathrm{A}} \pm 1.18$ & $36.59 \pm 3.51$ & 41.524 & 0.004 \\
\hline \multirow{3}{*}{$\mathrm{CIE}^{5)}$} & $\mathrm{L}^{*}$ & $54.24 \pm 0.95$ & $54.23 \pm 1.50$ & $55.23 \pm 2.07$ & $55.20 \pm 1.56$ & $54.72 \pm 1.49$ & 0.676 & 0.676 \\
\hline & $a^{*}$ & $9.42 \pm 0.80$ & $10.05 \pm 1.05$ & $10.11 \pm 0.62$ & $10.11 \pm 0.92$ & $9.92 \pm 0.83$ & 0.617 & 0.617 \\
\hline & $b^{*}$ & $3.52 \pm 0.34$ & $3.58 \pm 0.33$ & $3.51 \pm 0.25$ & $3.51 \pm 0.21$ & $3.53 \pm 0.26$ & 0.984 & 0.984 \\
\hline \multicolumn{2}{|c|}{$\mathrm{pH}$} & $5.80 \pm 0.37$ & $5.80 \pm 0.37$ & $5.87 \pm 0.10$ & $5.89 \pm 0.32$ & $5.89 \pm 0.63$ & 0.042 & 0.988 \\
\hline \multirow{3}{*}{$\begin{array}{c}\text { Sensory } \\
\text { evaluation }\end{array}$} & Juiciness & $4.32 \pm 0.46$ & $4.50 \pm 0.14$ & $4.56 \pm 0.79$ & $4.56 \pm 0.51$ & $4.48 \pm 0.48$ & 0.901 & 0.901 \\
\hline & Tenderness & $3.82 \pm 0.13$ & $4.14 \pm 0.29$ & $4.20 \pm 0.54$ & $4.20 \pm 0.29$ & $4.09 \pm 0.35$ & 0.384 & 0.384 \\
\hline & Flavor & $4.20^{\mathrm{C}} \pm 0.78$ & $3.61^{\mathrm{B}} \pm 1.58$ & $3.41^{\mathrm{A}} \pm 0.96$ & $3.41^{\mathrm{A}} \pm 0.18$ & $3.65 \pm 0.51$ & 0.005 & 0.005 \\
\hline
\end{tabular}

Data are presented as the mean \pm SD.

${ }^{\mathrm{a}-\mathrm{c}}$ Means with different superscripts in the same row are significantly different $(p<0.05)$.

${ }^{\mathrm{A}-\mathrm{C}}$ Means with different superscripts in the same row are significantly different $(p<0.01)$.

${ }^{1)}$ Control: basal concentrate, ${ }^{2)} \mathrm{T} 1: 0.3 \%$ Macsumsuk powder, ${ }^{3)} \mathrm{T} 2: 0.3 \%$ herb mixture, and ${ }^{4)} \mathrm{T} 3: 0.3 \% \mathrm{Macsumsuk}$ powder $+0.3 \%$ herb mixture, ${ }^{5)} \mathrm{CIE}$ values: $\mathrm{L}^{*}=$ lightness, $\mathrm{a}^{*}=$ redness, and $\mathrm{b}^{*}=$ yellowness 
$<0.05$ ) cooking loss of the pork comparing to the Control group. Shear force values were not altered $(p<0.05)$ by the treatments although the numeric values were decreased. Macsumsuk and the herb mixture did not affect the WHC of the pork. Assessment of meat color revealed that the overall average $L^{*}$ value was $54.72 \pm 1.49$, the $\mathrm{a}^{*}$ value was $9.92 \pm 0.83$, and the $b^{*}$ value was $3.53 \pm 0.26$. No significant differences among the groups were found. $\mathrm{pH}$ of the meat from all groups was similar with an overall average of 5.86 \pm 0.36 . Park et al. (1988) reported that feeding herbal medicine residues to pigs improves pork color and increases consumer demand for the meat.

In the sensory evaluation, the overall average score for juiciness associated with the WHC was $4.48 \pm 0.48$ while the score for tenderness was $4.09 \pm 0.35$. No significant differences $(p>0.05)$ among the groups were observed. In contrast, the flavor score for the Control group (3.65 $0.51)$ was statistically higher $(p<0.05)$ than those of the treatment groups. Kim and Kim (2005) reported that feeding powdered persimmon peelings to growing and fattening pigs improves the tenderness and juiciness of the pork. Hong (2006) found that the WHC, juiciness, and tenderness of the meat are improved while meat color values for redness $\left(\mathrm{a}^{*}\right)$ are increased by administering Lonicerac Caulis et Folium to fattening pigs. Addition of Macsumsuk and the herb mixture to the diets of fattening pigs significantly lowered $(p<0.01)$ the total cholesterol contents of pork from the treatment groups (34.10-36.15 $\mathrm{mg} / 100 \mathrm{~g}$ ) comparing to the meat from the Control group $(42.03 \pm 0.78 \mathrm{mg} / 100 \mathrm{~g})$. Results from the current investigation and a previous report by Pond et al. (1988) suggest that Macsumsuk may affect cholesterol contents of the pork.

The WHC is closely associated with $\mathrm{pH}$ levels of the meat. The WHC should be the lowest when $\mathrm{pH}$ of the muscle is close to the isoelectric point ( $\mathrm{pH}$ 5.0) of myosin and actomyosin (Pearson and Young, 1989). Changes in the structure of meat protein and ion concentration would increase the WHC (Wu and Smith, 1987). Tenderness and flavor are important sensory qualities that determine meat quality when cooked pork is chewed. Factors affecting tenderness and flavor may include fat contents, maturity of the meat, collagen contents, $\mathrm{pH}$, and moisture contents. The texture of meat is determined by complex interrelationships of these factors (Mottram and Edwards, 1983). The addition of silicate minerals to the diets of fattening pigs improves the odor, juiciness, and tenderness of pork while extended the shelf-life by delaying rancidification and improving overall palatability (Kong et al., 2004). Supplementation of the diet of pigs with 1-5\% powdered persimmon peelings increases the total cholesterol, HDL, and triglyceride contents of pork whereas the WHC is decreased Kim and Kim, 2005; Park et al. (2007) reported that feeding $2.5 \%$ by-products of Ginseng Radix may

Table 6. Effects of Macsumsuk and the herb mixture on the fatty acid composition of pork

\begin{tabular}{|c|c|c|c|c|c|c|c|}
\hline Items (\%) & Control $^{1)}$ & $\bar{T} 1^{21}$ & $\bar{T} 2^{3)}$ & $\mathrm{T}^{4)}$ & Average & F-value & $\overline{\text { P-value }}$ \\
\hline C14:0 & $1.18 \pm 0.15$ & $1.22 \pm 0.12$ & $1.20 \pm 0.27$ & $1.20 \pm 0.14$ & $1.20 \pm 0.16$ & 0.032 & 0.992 \\
\hline C16:0 & $23.99 \pm 1.41$ & $23.58 \pm 1.07$ & $23.19 \pm 0.83$ & $23.19 \pm 1.64$ & $23.49 \pm 1.19$ & 0.362 & 0.781 \\
\hline $\mathrm{C} 16: \ln 7$ & $2.75 \pm 0.21$ & $2.76 \pm 0.25$ & $2.99 \pm 0.35$ & $3.04 \pm 0.39$ & $2.89 \pm 0.31$ & 0.959 & 0.443 \\
\hline C18:0 & $13.10 \pm 1.42$ & $12.47 \pm 1.79$ & $12.90 \pm 0.49$ & $12.85 \pm 0.78$ & $12.83 \pm 1.12$ & 0.183 & 0.906 \\
\hline C18:1n9 & $43.45 \pm 1.22$ & $45.72 \pm 0.99$ & $45.01 \pm 1.36$ & $45.15 \pm 1.83$ & $44.83 \pm 1.51$ & 1.977 & 0.171 \\
\hline $\mathrm{C} 18: \ln 7$ & $2.55 \pm 0.21$ & $2.35 \pm 0.25$ & $2.47 \pm 0.87$ & $2.42 \pm 0.08$ & $2.45 \pm 0.42$ & 0.135 & 0.937 \\
\hline $\mathrm{C} 18: 2 \mathrm{n} 6$ & $11.02 \pm 0.76$ & $10.23 \pm 0.66$ & $10.41 \pm 1.61$ & $10.31 \pm 0.22$ & $10.49 \pm 0.91$ & 0.565 & 0.649 \\
\hline C18:3n6 & $0.05 \pm 0.04$ & $0.06 \pm 0.02$ & $0.05 \pm 0.02$ & $0.05 \pm 0.01$ & $0.05 \pm 0.02$ & 0.144 & 0.932 \\
\hline $\mathrm{C} 18: 3 \mathrm{n} 3$ & $0.47 \pm 0.07$ & $0.43 \pm 0.02$ & $0.44 \pm 0.02$ & $.044 \pm 0.02$ & $0.45 \pm 0.04$ & 0.882 & 0.478 \\
\hline $\mathrm{C} 20: \ln 9$ & $0.97 \pm 0.09$ & $0.96 \pm 0.10$ & $0.90 \pm 0.09$ & $0.90 \pm 0.15$ & $0.93 \pm 0.10$ & 0.472 & 0.707 \\
\hline $\mathrm{C} 20: 4 \mathrm{n} 6$ & $0.51 \pm 0.06$ & $0.55 \pm 0.06$ & $0.54 \pm 0.06$ & $0.54 \pm 0.03$ & $0.54 \pm 0.05$ & 0.438 & 0.730 \\
\hline Total & $100.04 \pm 0.02$ & $100.33 \pm 0.33$ & $100.09 \pm 0.10$ & $100.08 \pm 0.01$ & $100.14 \pm 0.19$ & 2.377 & 0.121 \\
\hline $\mathrm{SFA}^{5)}$ & $38.27 \pm 0.31$ & $37.27 \pm 0.85$ & $37.29 \pm 0.23$ & $37.23 \pm 1.50$ & $37.51 \pm 0.91$ & 1.296 & 0.321 \\
\hline $\mathrm{UFA}^{6)}$ & $61.73 \pm 0.31$ & $62.73 \pm 0.85$ & $62.72 \pm 0.23$ & $62.77 \pm 1.50$ & $62.49 \pm 0.91$ & 1.296 & 0.321 \\
\hline MUFA $^{7)}$ & $49.73 \pm 1.10$ & $51.80 \pm 1.34$ & $51.36 \pm 1.69$ & $51.51 \pm 1.59$ & $51.10 \pm 1.54$ & 1.665 & 0.227 \\
\hline PUPA $^{8)}$ & $12.01 \pm 0.86$ & $10.94 \pm 0.51$ & $11.35 \pm 1.58$ & $11.26 \pm 0.25$ & $11.39 \pm 0.93$ & 0.908 & 0.466 \\
\hline UFA/SFA $^{9)}$ & $1.61 \pm 0.02$ & $1.69 \pm 0.06$ & $1.68 \pm 0.02$ & $1.69 \pm 0.11$ & $1.67 \pm 0.07$ & 1.397 & 0.291 \\
\hline
\end{tabular}

Data are presented as the mean $\pm \mathrm{SD}$.

${ }^{\mathrm{a}-\mathrm{c}}$ Means with different superscripts in the same row are significantly different $(p<0.05)$.

${ }^{1)}$ Control: basal concentrate, ${ }^{2)} \mathrm{T} 1: 0.3 \%$ Macsumsuk powder, ${ }^{3)} \mathrm{T} 2: 0.3 \%$ herb mixture, and ${ }^{4)} \mathrm{T} 3: 0.3 \%$ Macsumsuk powder $+0.3 \%$ herb mixture, ${ }^{5)}$ SFA: saturated fatty acid $(\mathrm{C} 14+\mathrm{C} 16+\mathrm{C} 18),{ }^{6}$ UFA: unsaturated fatty acids, ${ }^{7)}$ MUFA: monounsaturated fatty acids, ${ }^{8}$ PUFA: polyunsaturated fatty acids, and ${ }^{9}$ UFA/SFA: unsaturated fatty acids / saturated fatty acids. 
decrease the rancidity of fats. Inclusion of Lonicerac Caulis et Folium in the diet of fattening pigs improves weight gain and feed efficiency along with meat juiciness and tenderness assessed by a panel test (Hong, 2006). These results were similar to the ones obtained in the current study. As a result sensory evaluations of pork are improved because of improvement in carcass grade, water holding capacity (WHC), and meat color which resulted in improved meat quality.

\section{Fatty acid composition}

Fatty acid composition of M. longissimus dorsi samples from the experimental pigs is shown in Table 6. Major fatty acids (in the order of abundance) were oleic acid, palmitic acid, stearic acid, and linoleic acid. Total saturated fatty acid concentrations of the Control group $(38.27 \pm 0.31 \%)$ tended to be higher whereas the total unsaturated fatty acid concentration was lower than that of the treatment groups. These differences were not significant.

The fatty acid compositions observed in the present study were similar to those described in the previous reports showing that oleic acid was the most abundant fatty acid when silicate minerals were added to the diets of pigs while the total fatty acid composition was unchanged (Kong et al., 2004). In addition, the oleic acid concentration was the highest in pigs fed a diet supplemented with $0.5 \%$ Lonicerac Caulis et Folium with no significant changes in total fatty acid composition (Hong, 2006). There is a positive relationship between saturated or monounsaturated fatty acid contents and meat flavor (Cameron and Enser, 1991). Furthermore, meat with high levels of saturated fatty acids might be more resistant to fat rancidification and have a more stable color (Du et al., 2000).

Intake of high oleic acid, a monounsaturated fatty acid, might help prevent diseases such as arteriosclerosis by decreasing triglyceride and/or cholesterol levels in the blood (Grundy, 1986). Additionally, high oleic acid levels improve the flavor of meat (Lunt and smith, 1991) and guarantee high scores in panel tests (Dryden, 1970). A high ratio of monounsaturated fatty acids/saturated fatty acids could be used to indirectly indicate better palatability and flavor of pork (Janiki and Appledorf. 1974).

\section{References}

1. AOAC (2004) Official Methods of Analysis. 15th Ed. Association of Official Analytical Chemists, Washington. D.C.
2. Cameron, N. D. and Enser, M. (1991) Fatty acid composition of lipid in longissimus dorsal muscle of Duroc and British Landrace pigs and its relationship with eating quality. Meat Sci. 29: 295-307.

3. Cho, J. H., Kwon, O. S., Min, B. J., Sin, K. S., Chen, Y. J., Hong, J. W., Kang, D., and Kim, I. H. (2004) Effect of herb and bio-ceramic complex supplementation on growth performance and meat quality characteristic in finishing pigs. Korean J. Food Sci. Anim. Resour. 22, 329-334.

4. Dryden, F. D. and Marchello, J. A. (1970) An influence of bovine muscle. J. Anim. Sci. 31, 36-41.

5. Du, M., Ahn, D. U., and Sell, J. L. (2000) Effect of dietary conjugated linoleic acid (CLA) linoleic/linolenic acid ration on polyunsaturated fatty acid status in laying hens. Poul. Sci. 79, 1749-1756.

6. Duncan, D. B. (1955) Multiple range test. Biometric. 11, 1-6.

7. England, D. C. (1975) Effect of zeolite on incidence and severity of scouring and level of performance of pigs during suckling and early postweaning. Rep. Oregon State Univ. 17th Swine Day, Spec. Rep. 447, 30-33.

8. Folch, J., Lee, M., and Sloane-Stanly, G. H. (1957) A simple method for the isolation and purification of total lipids from animal tissues. J. Biol. Chem. 23, 497-507.

9. Grundy, S. M. (1986) Comparison of monounsaturated fatty acids and carbohydrates for lowering plasma cholesterol. $N$. Engl. J. Med. 314, 745-749.

10. Harms, R. H. and Darmron, R. H. (1973) The influence of various dietary follers on the utilization of energy by poultry. Poul. Sci. 52, 2034-2041.

11. Hong, J. W., Kim, I. H., Kown, O. S., Lee, S. H., Lee, J. M., Kim, Y. C., Min, B. J., and Lee, W. B. (2001) Effect of Korean medical herb residue supplementation on the egg quality and serum cholesterol of laying hens and heat stress. Korean $J$. Poul. Sci. 28, 259-265.

12. Hong, M. A. (2006) Effects of feeing lonicera japonica thumb on the growth performance and meat characteristics in growing-finishing pigs. Keimyung University Graduate School. M.S. thesis.

13. Janiki, L. J. and Appledorf, H. (1974) Effects of broiling, grilling, frying and microwave cooking on moisture, some lipid components and total fatty acids of ground beef. J. Food Sci. 39, 715-722.

14. Kim, B. K., Jung, D. J., Lee, J. H., Hwang, E. G., and Choi, C. B. (2011) Comparison of growth performances and physico-chemical characteristics of Hanwoo bulls and steers of different slaughtering ages. Korean J. Food Sci. Anim. Resour. 31, 257-265.

15. Kim, B. K., Kim, Y. J., and Kim, S. M. (2004) Effects of feeding mugwort pelleted diet on the meat quality in pigs. $\mathrm{Ko}$ rean J. Food Sci. Anim. Resour. 25, 39-44.

16. Kim, B. K., Lee, J. H., Jung, D. J., Cho, K. H., Hwang, E. G., and Kim, S. M. (2010) Effects of feeding herb resources powder on meat quality and sensory properties in Korean native black goat. Korean J. Food Sci. Anim. Resour. 30, 811818.

17. Kim, Y. J. and Kim, B. K. (2005) Effect of dietary persim- 
mon peel powder on physico-chemical properties of pork. Korean J. Food Sci. Anim. Resour. 24, 393-398.

18. Kondo, J. and Wagai, B. (1968) Experimental use of clinoptilolitetuff as dietary supplements for pigs. Yonkai, May. pp. $1-4$.

19. Kong, C. S., Ju, W. S., Kil, D. Y., Lim, J. S., Yun, M. S., and Kim, Y. Y. (2004) Effects of silicate mineral filtered water and silicate mineral additive on growth performance and pork quality. Korean J. Anim. Sci. Technol. 46, 743-752.

20. Kovar, S. J., Ingram, D. R., Hagedom, T. K., Achee, V. N., Barnes, D. G., and Laurent, S. M. (1990) Broiler performance as influenced by sodium zeolite-A. Poult. Sci. 69 (Suppl. 1), 174 (Abstr).

21. Kwon, O. S. (2001) Effects of germanium biotite supplementation on the pig production. Dankuk University Graduate School. M.S. Thesis.

22. Lunt, D. K. and Smith, S. B. (1991) Wagyu beefs hold profit potential for U.S. feed lot. Feed Stuffs 19, 18-22.

23. Macksumsuk G. M. 2010. Research report. Macsumsuk, Co.

24. Mottram, D. S. and Edwards, D. S. (1983) The role of triglycerides and phospholipids in the aroma of cooked beef. $J$. Sci. Food Agri. 34, 517-523.

25. Nam, K. C., Du, M., Jo, V., and Ahn, D. Y. (2001) Cholesterol oxidation products in irradiated raw meat with different packaging and storage time. Meat Sci. 58, 431-435.

26. Park, J. C., Kim, Y. H., Jung, H. J., Ji, R. Y., Lee, S. D., Ryu, J. W., Jang, H. D., and Moon, H. K. (2007) Effects of dietary ginseng by-product on growth performance and pork quality parameters in finishing pigs. Korean J. Anim. Sci. Techonol. 49, 839-846.

27. Park, J. H. (2002) The encyclopedia of Chinese crude drugs. Shinlisangsa. pp. 14, 56, 69, 423, 770.

28. Park, K. R., Shin, J. H., Lee, S. J., Lim, S. S., and Sung, N. J. (1998) The formation of $\mathrm{N}$-nitrosamine in commercial cured products. 2. The effect of cooking methods on N-nitrosamine formation in commercial ham and sausages. J. Food Hyg. Safety 13, 406-411.

29. Park, P. W. and Goins, R. E. (1994) In situ preparation of fatty acid methyl esters for analysis of fatty acid composition in foods. J. Food Sci. 59, 1262-1266.

30. Pearson, A. M. and Young, R. B. (1989) Muscle and meat biochemistry. Academic Press, San Diego.

31. Pond, W. G., Yen, J. T., and Varel, V. H. (1988) Response of growing swine to dietary copper and clinoptiloite supplementation. Nutr. Rep. Int. 37, 795-780.

32. Ryu, K. and Song, G. S. (1999) Effects of feeding angellica by-products on performance and meat quality of Korean native chicks. Korean J. Poult. Sci. 26, 261-265.

33. Son, Y. S., Kim, S. H., Hong, S. H., and Lee, S. H. (1998) Effect of feeding bentonite and granite porphyry on ruminal buffering activity and fermentation pattern. Korean J. Dairy Sci. 20, 21-32.

34. SPSS (2010) Ver 17.0 User's Guide, SPSS INC.

35. Wu, F. Y. and Smith, S. B. (1987) Ionic strength and myofibrillar protein solubilization. J. Anim. Sci. 165, 597-605.

$\overline{\text { (Received 2014.2.12/Revised 2014.3.21/Accepted 2014.6.10) }}$ 